\title{
THE POLITICS OF DISCLOSURE AND THE FABLE Mary Jacobs
}

(Abridged version of a paper given at the Society's AGM, 2006)

This paper will argue that Sylvia Townsend Warner used the fable in the 1930s and " 40 s to explore a series of political, personal and literary imperatives. Warner and her lover Valentine Ackland joined the Communist Party of Great Britain (CPGB) in 1935. The qualities and functions required of a socialist literature were much debated by the Left circles in which they moved, as is evident in the monthly journal Left Review (October 1934 - May 1938). Its principal interest was the inter-relationships of politics and aesthetics, including the extent to which Soviet imperatives should influence English policy and practice. Concerns included the margins between art and propaganda; the rediscovery and promulgation of an underground stream of English radicalism exemplified by folk literature and people's history '; the right evaluation of bourgeois literature from the past ${ }^{2}$; the revitalisation of English through 'the proletarianisation of our language' 3 ; and the encouragement and eventual publication of worker-writers ${ }^{4}$. The fable allowed Warner to address several of these issues.

Left Review contributors' anxiety about political writing showing its hand too plainly as vulgar propaganda under the influence of Soviet socialist realism might be appeased by the fable's narrative plenitude, offering second and even third levels of meaning. Their reclamation of English folk culture as a radical underground tradition could coalesce, in the fable's presentation of Everyman, with interests in Engels' notion of 'typicality'; bourgeois individual 'character' is replaced by depiction of the collective. Its simple diction 
would answer calls for 'the proletarianisation of our language'; and the fable's status as a form with both folk and classical provenance would serve the widest readership: in touch with tradition and hence preserving the "cultural capital' of the past, yet excluding nobody, least of all the worker-writers whom Left Review hoped to encourage.

Such Party concerns dovetailed with those characteristics of the fable which appealed to Warner's personal aesthetic: multiple and secret meanings, riddling qualities, investment in the figure of the storyteller, and what Walter Benjamin called 'chaste compactness's. Much of her previous work had explored the pastoral, which shares some properties with the fable: dual status as both classical and folk art, non-Christian archaism, and ambiguities in its relationship to history6. This match between the Party's and the writer's personal concerns encouraged Warner's adoption of the fable as a means through which to explore contemporary political and aesthetic questions.

As a zealous Party member, Warner found the form of the fable an appropriate one. Her friend Cecil Day Lewis had already proposed the potential of 'parable', 'fairy tales' and 'allegory' as 'a unique channel of political education' in contrast to explicit propaganda: because they are primitive, because they are universal,

because they do not argue and browbeat, [they] can slip past the defences of our intellect ... Cinderella, the Tin Soldier, the Prodigal Son can go into places where there is no admittance for Herr Goebbels or the Board of Education?

Warner's review of a collection of children's fairy stories for Gollancz's Left News refers to their potential 'to bring up a generation of little socialists'8. It's therefore surprising to find no evidence in Left Review or its successor Our Time of any political fables other than her own. Ironically, the political fable best known to us from this period is Orwell's Animal Farm (1945) whose politics are of course directly opposed to the Russophilia of Left Review which Warner then warmly shared. Despite the potential match between some features of English Marxist aesthetics and the fable, Warner's use of the 
form was unexpectedly rare within these circles, and all the more remarkable.

The fable's talking animals, brevity, simplicity and didacticism presuppose an unlettered, childlike audience, but Aesop's subject-matter and morality are at best pragmatic, at worst brutal9. There are further indications of the form's double tongue. Unlike allegory's elaborated narrative, the brevity of the fable appears to offer an uncompromising certainty of interpretation. Generally concluding with a moral often delivered in the form of an epigram, the fable's primary, 'story' level is often only sketchily evoked, urging the reader on towards 'the meaning'. But this notion of reading through the fable for its meaning can be complicated. While the 'moral' meaning of the Br'er Rabbit stories may be readily caught, the sense in which the originals also conveyed another coded, resistant, 'political' meaning to their early African American audience was intended to escape the notice of their white transcribers, and may remain obscure to readers today. The fable then, despite its homiletic reputation, carries the seed of a subversive message: in effect, a secret, third level of meaning. It resembles the parable whose essential moral meaning, while clearly didactic, is also bafflingly open to interpretation: 'He that hath ears to hear, let him hear'. Warner described After the Death of Don Juan not only as a political fable but also as an allegory and as a parable ${ }^{10}$. Accepting her elision, and using the term 'fable' as shorthand for this kind of encrypted writing, what can we conclude about its function as political polemic in Warner's work? How far and how fast does it want to be understood on its secondary or tertiary levels? Why is it 'partially hidden' and from whom?

Although Warner's work is regrettably still relatively unknown, her present reputation depends upon three different analyses. Because her life was long and her writings remarkably diverse, she is variously understood as a lesbian writer $^{11}$ and as a Leftwing writer ${ }^{12}$ but also, and especially in America, she continues to be read as a miniaturist of upperclass English life. The publicity for Viking's 1982 edition of Scenes of Childhood, for example, entices American readers with the promise that Warner's stories will 'evoke a world of 
nannies, butlers, pet poodles, English public schools, "good works", English country churches...' Lesbian, Leftist, lady: how is each of these manifestations related to her fables' textual secrecies, and to their politics of disclosure?

Like so many others, Warner joined the Communist Party of Great Britain in 1935. Unlike many others, she remained a member for another twenty years, never publicly retreating from her explicitly Left allegiance. In the 1930s and 1940s she regularly wrote and organised for Left Review, Country Standard, Left News, Our Time and other CP-orientated journals. However, at exactly the same time (1936) she began publishing vignettes representing English eccentricities in The New Yorker. So successful were these idiosyncratic stories that the prestigious magazine gave Warner a covetable 'first reading' contract. Her relationship with The New Yorker, her 'gentleman friend', was to continue for another forty years, giving rise to the publication of eight collections of her short stories, the majority of which had first appeared in the magazine.

In the 1930s and 1940s then, Warner's writing responded not only to the dictates of $\mathrm{CPGB}$, to which she remained fiercely loyal, but also to the constraints of the literary market-place. The extremes of this span of work are exemplified by the publication within a year, on the one hand, of her Left Review discussion of Dimitrov's aesthetic imperatives as outlined to the Soviet Writers' Association: 'Literature must serve the great revolutionary ideal of millions of workers'13; and on the other, of her high-spirited autobiographical story in The New Yorker, 'My Mother Won the War'14. Although Archive manuscripts show the time and trouble Warner devoted to both kinds of work, these aspects of her writing may appear unconnected. However, a littleknown collection of stories published in America in 1940 as The Cat's Cradle-Book ${ }^{15}$ shows Warner negotiating the gulf between these apparently polarised positions, using the form of the fable - with its layers of meaning and embedded textual secrets - to do so. This obscure text, which did not even appear in this country until 1960 , facilitates a reading of Warner in which her various manifestations as lesbian, as leftist and as English lady are not only simultaneously present 
but can in fact be understood as interdependent, through a politics of textual and sexual disclosure. First though, I'll discuss two of her other fables from this period: "An English Fable'16, and 'The Bear'17.

'An English Fable' is self-evidently a comment on the Public Order Act, rushed through in December 1936 after the Battle of Cable Street in October and the Hunger March two months later. The sheep may be read as the East End Jews or as CPGB members, the dogs as Mosley's British Union of Fascists, the sheep-dogs as the police and the Bailiff as the spirit of bourgeois democracy in cahoots with Fascism. Particularly precise references confirm this reading: the prohibition on dogs wearing collars alludes to the provision within the Act banning political uniforms; indeed, the Public Order Act is actually named. However, Warner's fable was juxtaposed in Left Review with Pablo Neruda's Republican poem 'Almeria', each occupying a full, facing page. This placing adds new dimensions to the meaning of 'An English Fable': the wild dogs can now be understood as the Falangists, and the attacks on the sheep as the fateful rebellion by elements of the army from the newly-established Republic to follow Franco. Wendy Mulford's is the only published critical comment on this brief text of Warner's and she reads it exclusively in this Spanish context: 'During the Spanish Civil War she had published a fable portraying the Spanish people as sheep set upon first by a band of wolves and then, under the even-handed justice of the bailiff, who above all "loved to hunt", by those who were supposed to be their guardian dogs' 18 . Perhaps Mulford proceeds too quickly to what is certainly a secondary level, or, if we had ever wanted to believe that the story was actually about animals, even a third order of meaning; however, this fable is entirely capable of such extension. Indeed, an important aspect of Warner's use of fable in relation to political disclosure is its propensity to generate meanings above and beyond the immediate political context. Therefore a fourth level of meaning can be inferred, whereby the text conveys a paradigmatic Marxist message about relations between the Law, the Left and Fascism. Warner's satirical net is spread 
even wider as the fable's apparently naïve register echoes that of Biblical discourse: 'And on a certain day he came forth'. So God too turns a blind eye to Fascism, an implication shared by Neruda's anti-clerical poem on the opposite page.

Warner's 1939 fable 'The Bear' is a more developed but less emblematic narrative about the role of the U.S.S.R., the eponymous bear, in the coming revolution, vis- $\grave{a}$-vis the major European powers, depicted as carefully differentiated dogs. Never published in Warner's lifetime, the allegorical complexity of its detail limits its effectiveness. We can laboriously deduce that the action of the big dogs in falling upon a smaller dog alludes to the suppression of the socialist uprising led by Bela Kun in Hungary, or that their later 'assimilation' of various small dogs refers to Italy's annexation of Ethiopia and Germany's incursion into Sudetenland. The narrative effect is limited to that of readerrecognition: this fable is not disclosing secrets so much as encrypting answers. Warner's own impatience with this limitation is evident in the relish with which she escapes from the allegorical straitjacket into an outburst of almost hysterical narrative invention satirising the discourses of contemporary advertising as the capitalist fleas urge the dogs representing the European powers to attack Russia, the bear:

'Bear!' sang a fresh chorus of fleas. 'Nature's own remedy. Bear, the sure speedy cure for all ills. Strengthens weak dogs. Positively ends the tired feeling ... Revealed by grateful Indian widow to colonel's wife. Sends the rich red blood coursing through the veins. Unequalled for clergyman's sore throat...'

Both examples show Warner's use of the fable in the service of her Communist beliefs. Political disclosure is relatively straightforward: links are made between historical periods to demonstrate how the interests of capitalism and nationalism exploit the workers and engender suffering for the poor. However, sexual politics are also woven into the fabric of Warner's fables.

The central characters of Summer Will Show 19 are two women involved in the July Days of 1848: Minna Lemuel, a Jewish radical and storyteller, and Sophia Willoughby, an 
English landowner turned political activist. We cannot doubt that the women are lovers, although some 1930s reviewers insist that they are, for example, 'enjoying a helpful and stimulating friendship'. Terry Castle's 1993 reading of this novel in The Apparitional Lesbian has been influential; part of her interpretation turns upon a narrative ellipsis, a rhetorical device ideal for the partial disclosure of secrets, and of which Warner was extremely fond. This ellipsis both encrypts and discloses Minna and Sophia's first night together:

'I will stay if you wish it.'

It seemed to her that the words fell cold and glum as ice-pellets. Only beneath the crust of thought did her being assent as by right to that flush of pleasure, that triumphant cry.

'But of course,' said Minna a few hours later, thoughtfully licking the last oyster shell, 'we must be practical.' (274).

Of this passage, Castle remarks, 'The meaning is clear', though as we have seen, perhaps not to all 1930s readers. He that hath ears to hear, let him hear. Sexual/textual secrecy on this topic is not unusual: several studies, notably Julie Abraham's ${ }^{20}$, have shown how lesbian narratives of the period and indeed later, are displaced into historical novels describing gay male relationships: Naomi Mitchison and Mary Renault are two of many such examples. Warner does not offer an explicit, matter-of-fact depiction of lesbian relations. While 'A Love Match', her story describing a postwar incestuous brother-sister relationship has been read as another displaced, disguised lesbian narrative ${ }^{21}$ and her 1927 novel Mr Fortune's Maggot deals with a missionary who finds himself in love with a young male South Seas islander, Summer Will Show is the nearest Warner comes in her published work to disclosure. The narrow margin between textual disclosure, political power and personal danger is signified by Minna, who explains how telling a fable in Vienna had nearly led to her imprisonment for sedition:

'I was being very harmless, I was telling my fairy-stories. I described an ogre, a sleek grey ogre, sleek as ice. Wherever he went I said, it was like a black frost. Whatever he touched stiffened, birds fell dead, the young fruit dropped off the trees. The name of this 
ogre, I said, was Mitternacht - you know what they call Metternich. There were some students in the audience and in an instant they were up, shouting and applauding' (272).

Here the hidden, 'political', third level of fable, akin to the secret messages of the Br'er Rabbit stories hiding beneath their 'very harmless' surface, is recognised by the initiates, the story's revolutionary power is unleashed - and Minna is nearly imprisoned by the state. Full disclosure rather than the oblique suggestion of such secrets is always dangerous; here Warner suggests that too ready a recognition of the embedded elements by those already 'in the know' nearly wrecks the fable's ultimate revolutionary potential.

In these years then, Warner was publishing Mass Declamation poems for collective recitation like 'Red Front!' in Left Review, offering Marxist (re)readings of history in her novels, and composing the overtly political fables discussed above. At the same time, as we have seen, her quintessentially English stories, many of them autobiographical, were finding a regular home in The New Yorker. So how are we to place her simultaneous creation of The Cat's Cradle-Book, a collection of fables and folk tales purportedly told by nursing cats to their suckling kittens? What might the mostly male Party officials at CPGB HQ in King Street have made of the latest production by the woman they knew as 'Comrade Townsend-Warner'? Are these stories to be understood as more arch wit and English charm for The New Yorker readership? If so, then conversely, how might William Maxwell, her editor there, have responded to a Cat's Cradle-Book story like 'The Magpie Charity'? This animal fable offers a forensic analysis and a blistering critique of the concept of charity embodied in the 1834 Poor Law and notoriously dispensed by the Public Assistance Committee 'the Poor Law under another name' - to the British unemployed in the 1930s. 'The Magpie Charity' was in fact published in The New Yorker in 1940, though it remained unseen in Britain until its appearance in the May Day issue of Our Time in 1948. By that time of course, the principal legislation of the Welfare State was in place and the immediate political potency of Warner's furious fable - though not its 
underlying economic analysis - was largely spent.

The Cat's Cradle-Book consists of seventeen stories. True to fable tradition, most take animals as their protagonists, most are brief, and none has a historically specific setting. The collection is governed by its opening tale, the sumptuously-written, disquietingly erotic 'Introduction'. This riddling text marks itself off from the rest of the set by greater length but more importantly by its masquerade as an editorial 'introduction' to what follows. From the start then, its status as narrative is mysterious: it seems to offer a documentary that comments on the provenance, acquisition and significance of the Cat's Cradle-Book stories themselves; but because it also features talking cats and cross-species sexual relations, it asks to be read as fantasy. Full of historically precise referents - one character quotes Havelock Ellis, another drives a Riley, the price of a male kitten is $2 / 6 \mathrm{~d}$ - its tone of languorous and erotic reverie simultaneously places the events it describes outside time. In its sophistication of detail, 'Introduction' at first seems far from the world of fable as form, though its content is loaded with narrative secrets and heavy with implied meanings. And of course it $i$ full of talking cats...

The story opens arrestingly with a single-sentence paragraph, as an unnamed woman narrator stops her Riley to get a better look at a beautiful old house, and finds herself caught up by its equally beautiful owner: 'I had never seen a handsomer young man'. In fantasy tradition, 'Introduction' gradually conducts narrator and reader away from the realm of recognition and into a different, exquisite and unsettling world, poised on the cusp of dissolution: "the house lay like a pear fallen from a tree - a pear beginning to grow sleepy'(9). Many resident cats of various names, markings, talents and dispositions introduce themselves to the gratified narrator. The 'young man', though classily insouciant, is commanding: 'there was ownership in every inch of him'. During an enchanted night, a series of interlocking narratives unfolds: the young man tells of his initiation by his first cat lover, Haru, into the secret tradition of cats' tales; he describes his passionate collecting and cross-referencing of cats' fables 
from different lands and the editorial quandaries they pose; and he expounds his theorising, anthropological and narratological, about the transference of cats' stories to the realm of human culture. A highly-lacquered, mannered, languorous style characterises Warner's telling of the tale. After a visit to the nursing kittens and an elegant dinner, the beautiful young man and the woman motorist (inevitably) make love in the garden:

Deftly he knocked me over, and with a sigh began to make love to me. The mossy grass was deep and cool, and in an interval of love I praised it.

'It has never been cut,' said he, 'except with a scythe. While I am here it never will be.' (36-37).

The tone, calculatedly predatory, elegant and cool, resembles that in which the young man himself has earlier narrated the fate of Haru:

'After her death (for I was determined not to mutilate her memory by any sentimental faithfulness) I took another cat, a male neuter, a charming guttersnipe'. (20).

So what has this gorgeous, thinly-veiled erotica to do with the world of Left Review, with that dictum of Dimitrov so dear to Warner: 'Literature must serve the great revolutionary ideal of millions of workers'? And alternatively, what has it do with that other fable, the displaced lesbian narrative? At first glance it seems easier to locate the tale within the context of the ineffably upper-class Englishness so lovingly satirised by Warner in her New Yorker texts. However, beneath the japoniste detail there are plenty of clues.

The exquisite setting, we are told in a brief afterword that identifies the young man as 'the late Mr William Farthing', is none other than 'Spain Hall, Norfolk' (45). This textual secret alerts us to the work's potential for a politicised reading, as does its more explicit praise of the U.S.S.R.:

No literary commissar in Soviet Russia (a fine country. I like it.) could have a clearer notion of the social function of literature than a cat has (23-24). 
How then should we read the significance of these cats and the culture that their stories represent, in Warner's fable? Like 'An English Fable', this text generates more than one level of meaning. The cats, depicted throughout as the guardians of a various and vital folk culture with a lively oral tradition, may be read as the revolutionary potential of the British working classes, but equally well as the Spanish Popular Front. In either reading, a third level is implied: it is the difficult necessity of the intelligentsia's 'going over' to collaborate with the workers in the class struggle.

It is in Spain Hall then, that the beautiful young man has been wrestling with the questions inherent in collecting, transcribing, editing and publishing the cultural products of a folk tradition not one's own. These issues of class and culture, transcription and possession, echo those that preoccupied Warner and her comrades. Gravely they set and judged 'Competitions' in Left Review for worker-writers ('The subject is either an hour or a shift at work ... Another scene which would have great possibilities would be men at work on a building job'22); with equal passion they translated and published the romanceros, folk ballads of the Spanish people which celebrated their struggle against Franco and commemorated their Republican dead. Manuscripts in Warner's Archive demonstrate the seriousness with which she undertook her excellent translations of these romanceros ${ }^{23}$; her Left Review work reveals her efforts not to patronise the worker-writers: the 'Competition' she set and judged, for example, was unique in inviting them to act as literary critics ${ }^{24}$. But the risks of paternalist intervention by the intelligentsia are highlighted as the young man of Warner's fable reproves himself for having adapted rather than transcribed one of the cat's-cradle stories, 'Bluebeard's Daughter':

It's a farrago I constructed from her material - educated oaf that I was, thinking I could improve on perfection! And I have never found it again, which serves me right. (32).

Similarly, a nicely self-referential discussion about possible publication of the stories airs the anxieties felt within 
Left circles about relationships with capitalist publishing houses and the ways in which the socialist message and the workers themselves might be misrepresented by them:

Cat is not a recognised language. How are you to convince people that what is roughly a vocabulary of mew and guttural can convey such fine shades of meaning?(34).

The narrator warns the young man of the dangers commodity capitalism might bring to the cats' culture should they unwittingly act as its agents in promoting the stories:

...publicity impresarios would exploit and misrepresent them, their cultural heritage, guarded so long and so scrupulously, would be laid open to commerce and prettification, incalculable harm and misery might be the end of our beginning.(36).

Warner's fable alludes to another Left Review concern: the relationship of art to propaganda. Although the cats' stories are certainly 'instructive', the young man insists on their distinction from 'the ordinary moral tales, the ordinary webfooted propaganda' (25). Their political content enhances rather than conflicts with their aesthetic qualities. 'Introduction' continually stresses the inherent excellence of this indigenous cat-culture. Once the relationships of equivalence have been established, what does this fable, and its relationship to the sixteen stories that follow, actually have to say about class, culture and politics?

Firstly, the cats' underground tradition transcends both cultural differences and individual artistry:

Yes, here, in a disused pigsty in Norfolk, a poor unlettered tabby was repeating to her kittens a story of Indian life which I had first heard from the lips of my Siamese cat in Ankara. (22).

Walter Benjamin observed that 'the perfect narrative is revealed through the layers of a variety of retellings' 25 ; the individual teller neither engenders nor possesses it. The stories within The Cat's Cradle-Book draw on Norse, Greek, Irish and Indian traditions, Middle European folk tales and the Arabian Nights, but whatever their provenance they share the same preoccupations: class, gender, religion, art, cultural 
production and cultural value. As their collector says in 'Introduction', 'I think you are attaching far too much importance to nationalities ... the culture of cats transcends mere racial accidents' (27). In Warner's fable then, whether the oral culture of cats suggests the Spanish Popular Front or the revolutionary potential of the English working classes, class identification is the telling factor. 'Workers of the world unite': international socialism is the way forward. Warner's 1939 autobiographical essay on her political education, 'The Way by Which I Have Come', takes a similar analysis, linking British rural labourers with 'their fellows in other countries ... those peasants in Spain, defending their olive and orange co-operatives' and 'the new tractors swinging over the U.S.S.R. collective farms' 26 .

Secondly, 'Introduction' also insists on the anteriority and superiority of the cats' indigenous culture:

Why not suppose that our stories came to us from the cats? Try to clear your mind of humanism and consider the evidence. Where do we find the stories most constant, most uncontaminated? Among the cats. It is among the misunderstanding forgetful humans that they become corrupt and prejudiced... (30).

The relation between cat and human culture can here be read as that between a vital folk culture, the model valued by the English Marxists, and an attenuated bourgeoisie, figured here as 'humanism', and characterised as 'heated and sentimental' in contrast to the 'catholic, explicit, unvarying' qualities of Cat. The power of this vital folk culture will not be acknowledged, the story tells us, 'until the coming of a more rational age': scientific socialism. Meanwhile, there is great danger: 'And at any moment a declaration of war, an air raid ...' (36). This reminder of a world poised on the brink of destruction outside the enchanted manor house, is a harbinger of the disaster with which the story closes, to which I will return.

First though, I want to revisit the displaced lesbian narrative, that alternative fable of Warner's, and its interaction here with her leftist one. 'Introduction' emphasises throughout that the cats' storytelling tradition is matrilineal: 'Fortunately most people want toms, and for my purposes females are best' 
(28). The 'down-at-heels' Irish tabby Mrs O'Toady, supreme teller of the cat's cradle-book stories, is, like Minna Lemuel, the Jewish radical storyteller in Summer Will Show, and Engracia Hernandez, the girl ballad singer in After the Death of Don Juan, an outsider and an artist of the streets; all are marginalised but also strengthened by their gender, ethnicity and class, upon which, Warner suggests, their artistry depends:

We stood for some minutes silently admiring Mrs O'Toady's motherhood, the look of ineffable contentment on her small mean face, the dignity of her abandoned attitude. At length she rolled over, dragged the three kittens into her embrace, and began to lick them. As we left the stable she was saying in a drowsy voice: 'Once upon a time there was a dog who had thieved a bone...' (15).

Here then, the folk tradition whereby the storyteller's outsider status is the source of her strength is upheld, but Warner has added gender and ethnicity to the CP-sanctioned dimension of class solidarity. In terms of orthodox political analysis then, there is a contradiction here. While the Party line is followed in William Farthing's emphasis on the collective production of culture, and in his dismissal of nationality as 'a mere racial accident', it is tellingly undermined by admitting the peculiar artistry of those outlawed by reason of their ethnicity, their gender, and, if we have ears to hear, even their sexuality. Certainly a gendered aspect to the formation and transmission of culture is proposed here; as the young man says, 'The milk flows, and the narrative flows with it' (24). Nonetheless, there is nothing definitively 'lesbian' in this secret female tradition, despite an emphasis on its outlaw status. Indeed, its surrogate, male gay sexuality, has been markedly absent from 'Introduction'. However, the politics of sexual/textual disclosure are at work in an additional level of the fable, one in which Warner's manifestations as lesbian, leftist and lady are interdependent.

A hidden narrative runs contrapuntally throughout 'Introduction', disclosing, though only to initiates, a range of references to Warner and Ackland's life together. The young man's physical appearance, manners and idiolect instantly recall the good-looking, jodhpur-wearing, rifle-toting 
Valentine who had volunteered for lorry-driving in the Spanish Civil War. So recognisable was this portrait that intensely Valentine-specific references were toned down twenty years later for Chatto's British edition ${ }^{27}$. Similarly, the enchanted home shared by the young man with his cats is an image of Frankfort Manor, the seventeenth-century house in Norfolk to which Warner and Ackland had moved in 1933, faithful in every detail down to the long grass, cut only with a scythe. The language by which it is evoked in 'Introduction' is identical with that of Warner's diary and letters ${ }^{28}$. The arrival of a tradesman's cart with food for the cats contains another textual secret: 'Painted on the tail-board were the words: Craske. Fishmonger' (14). John Craske was the Norfolk fisherman and naïve painter whom Warner and Ackland had befriended and whose work they had championed and introduced to the London galleries. This is of course another example of the Left intelligentsia 'going over' in cultural politics, akin to their encouragement of workerwriters in Left Review and to the high value that The Cat's Cradle-Book places on the stories of a cat 'of lower social standing', the 'down-at-heels' Mrs O'Toady. One final feature of the fable's secret lesbian narrative returns us to the story's closing disaster, mentioned earlier. This last stage continues to interweave the worlds of leftist, lesbian and lady, as the threat of war outside is replicated by destruction within.

'Introduction' ends with the narrator urgently recalled by a telegram: 'They are all dying. Please come at once. London died at 5.30 this morning' (38). The cats have been wiped out by a 'murrain', or plague, exactly as had happened to Warner and Ackland's cats at Frankfort Manor ${ }^{29}$. But the fable reaches beyond this encrypted biographical level to wider political applications. A first draft of Camus' La Peste also dates from 1940: we may well feel that 'the meaning is clear'. And yet there are even further textual possibilities for political disclosure than this obvious warning against the Nazi plague already at its poisonous work in Europe. Although by this point an elegy for Spain had become all too appropriate, the fight against Fascism on a wider front was barely begun: why would Warner's fable close with the 
extirpation of a culture representing the class she has invested with such transformative political significance? Earlier William Farthing has insisted on the cat-culture's durability in the face of 'a declaration of war, an air-raid': 'We must rely on the cats. It is their business, and no doubt they know how to manage it' (36). But the fable's last five pages signal, with genuine pathos, the absolute collapse of this vibrant underground culture. Only the slenderest shred of hope remains: though Mrs O'Toady seems to be dead, her daughter Owly, 'a foolish, almost witless creature', survives. Even this possibility seems overshadowed by the fable's sombre closing words: 'All was at an end' (44).

This may reflect yet another level of the fable's political disclosure, and for Warner, a deeply personal one. While the CPGB had expressed wholehearted support for the war at its outbreak, the Nazi-Soviet pact of August 1939 had provoked fierce internal debate, causing confusion and demoralisation throughout the Left. Warner's regular Communist newspaper The Daily Worker had described the war as 'unjust and imperialist' 30 . The gloomy conclusion of 'Introduction' may thus be encrypting a further personal secret: her internal struggle with a loss of faith and a crisis of allegiance. Her opposition to Fascism was total, but her loyalty to Soviet Russia and the Communist Party very great. These were desperate times, in which it was hard for Warner to continue to believe in the solidarity of the working classes and the triumph of international socialism. Perhaps it was no longer possible for her to think that in the end the cats would 'know how to manage it'.

1 The notion of an underground stream of English radicalism is especially evident in the works of Edgell Rickword, Wamer's close friend and later editor, and Jack Lindsay. See for instance, Edgell Rickword, 'Culture, Progress and English Tradition' in Cecil Day Lewis (ed.), The Mind in Chains: Socialism and the Cultural Revolution, London: Frederick Muller, 1937, pp.235-256; and Jack Lindsay and Edgell Rickword ( eds.), A Handbook of Freedom: A Record of English Democracy through Twelve Centuries, London: Lawrence and Wishart, 1939.

2 Montagu Slater, Left Review I: no.4, Jan.1935, pp.125-128, outlines a 
policy for preserving and using the 'stored-up literary labour of the past', which he identifies as 'cultural capital'.

3 The patrician archaeologist Alec Brown, in Left Review I: no. 3, Dec. 1934 , p.76, calling for 'the proletarianisation of our language' asserts that 'WRITTEN ENGLISH BEGINS WITH US'.

4 Left Review's policy of encouraging worker-writers through Competitions and appraisal of their unpublished work was modelled on the aim expressed at the 1934 Soviet Writers' Congress, reported by Amabel Williams-Ellis, Left Review I: no. 2, Nov. 1934, pp.17-28: 'Our method of helping proletarian writers is to devote great work to their cultural advance, to bring them into contact with great masters of language, to print their still imperfect works and to criticise them frankly'. In March 1935 the journal carried a major feature of workerwriters' accounts of 'A Shift at Work', set as one of the Competitions. The contributors were described as including: 'The Turner, the Tailor, the Waitress, the Student, the Washerwoman, the Toolsetter, the Thresher, the Porter, the Boy at the Milking-Stool'. Warner's close friend Julius Lipton was 'the Tailor'.

5 For Warner and the pastoral, see John Lucas, The Radical Twenties: Aspects of Writing, Politics and Culture, Nottingham: Five Leaves Publications, 1997; and Mary Jacobs, 'Sylvia Townsend Warner and the Politics of the English Pastoral 1925 - 1934' in (eds.) Gill Davies, David Malcolm, John Simons, Critical Essays on Sylvia Townsend Warner, English Novelist 1893-1978, Edwin Mellen Press, 2006.

6 Walter Benjamin, 'The Storyteller' in Illuminations, tr.Harry Zohn, London: Fontana, 1992, p. 90.

7 Cecil Day Lewis, 'The Revolution in Literature' in Revolution in Writing, London: The Hogarth Press, 1935, pp.16-17.

8 Sylvia Townsend Warner, review of The Adventures of the Little Pig and other Stories by F.Le Gros Clark and Ida Clark, Left News, September 1937, p.514.

9 See S.A.Handford's 'Introduction' to Aesop's Fables, Harmondsworth: Penguin Classics, 1983, p.xx for the view that the fables' morality is 'merely counsels of prudence and worldly wisdom'.

10 Sylvia Townsend Warner, letter to Nancy Cunard, 28.xii.1945, Letters (ed. William Maxwell), London: Chatto \& Windus, 1982, footnote, p.51, refers to ADDJ as 'a parable, if you like the word, or an allegory or what you will, of the political chemistry of the Spanish Civil War', while thirty-six years later she describes it as "definitely a political novel - at least perhaps I should say it's a political fable', in an interview: 'Sylvia Townsend Warner in Conversation', in Sylvia Townsend Warner 1893 - 1978: A Celebration, in Poetry Nation Review (23), 1981, p.35.

11 See for example Terry Castle, 'Sylvia Townsend Warner and the Counterplot of Lesbian Ficțion' in her The Apparitional Lesbian, New York: Columbia University Press, 1993, and Gay Wachman, Lesbian Empire: Radical Crosswriting in the Twenties, New Brunswick, New Jersey: Rutgers University Press, 2001. 
12 See for example Janet Montefiore, Men and Women Writers of the 1930s: The Dangerous Flood of History, London: Routledge, 1996, and Maroula Joannou, 'Sylvia Townsend Warner in the 1930s' in Andy Croft (ed.), A Weapon in the Struggle: The Cultural History of the Communist Party in Britain, London: Pluto, 1998.

13 Sylvia Townsend Warner, 'Competition in Criticism', Left Review II: no.1: Oct.1935, pp.32-33.

14 First published in The New Yorker in 1936, reprinted in Scenes of Childhood, London and New York, Chatto \& Windus, 1981.

15 Sylvia Townsend Warner (1940) The Cat's Cradle-Book, London, Chatto \& Windus, 1960; hereafter referenced by page number.

16 Sylvia Townsend Warner (1936) Summer Will Show, London: ViragoPenguin, 1987 and (1938) After the Death of Don Juan, London: Virago, 1989; both hereafter referenced by page number.

17 Left Review III: no.7, Aug.1937, p.406.

18 Sent as a Christmas present in a letter to Edgell Rickword's wife Johnnie, dated 24.12.1939, published in Sylvia Townsend Warner 1893 - 1978: A Celebration, in Poetry Nation Review (23), 1981, pp. 48-50.

19 Wendy Mulford, This Narrow Place: Sylvia Townsend Warner and Valentine Ackland: Life, Letters and Politics, 1930-1951, London: Pandora Press 1988, pp. 192-193.

20 Julie Abrahams, Are Girls Necessary? Lesbian Writing and Modern Histories, London and New York: Routledge, 1996.

21 Christine Daley, 'Ghostly Confidences: War and Transgressive Sexuality in Sylvia Townsend Warner's 'A Love Match', http://www.womenwriters.net/editorials/alovematch.htm.

22 Amabel Williams-Ellis, 'Our Readers Get to Work', Left Review I: no.3, Dec.1934, p.74.

23 See Warner's translation of Urutia's romancero on the murder of Lorca in (eds.) Stephen Spender and John Lehmann, Poems of Spain, London: The Hogarth Press, 1939, pp.105-108; and (ed.) Valentine Cunningham, The Penguin Book of Spanish Civil War Verse, Harmondsworth: Penguin Books, 1996, for Warner's translations of romanceros by Francis Fuentes, Julio D. Guillen, Jose Herrera Petere and Felix Paredes.

24 Sylvia Townsend Warner set the Worker-Writer Competition, 'Competition in Criticism', in Left Review II: no.1, Oct.1935, pp. 32-33; she invited worker writers to offer critiques of two stories.written by worker writers in response to an earlier Competition on the subject 'Strike!' Her adjudication report was published in Left Review II: no. 4, Jan. 1936, pp. 178-179.

25 Walter Benjamin, 'The Storyteller',op.cit., p.92.

26 Sylvia Townsend Warner, 'The Way by which I have Come', The Countryman XIX: 2, July 1939, pp.472-486. The quotation comes from pp.485-486.

27 See 1940 American publication of The Cat's Cradle-Book, description of the young man Mr William Farthing in the opening story, 'Introduction': 'Tall and slender, grey-eyed, with straight ash-blond hair, 
he was the spit and image of the classical English type which is proverbially dressed in very well-cut clothes that are also very old but also very well-kept. Actually, he was wearing a pair of ready-made corduroy trousers still smelling of the shop, and a strawberry-coloured cotton shirt that must have been bought either in Harlem or at one of the wilder branches of Cent Mille Chemises. He was holding a rake, and a lock of hair fell over one eye.' This may be compared with the 1960 English publication of The Cat's Cradle-Book, revised description of William Farthing in 'Introduction': 'Like a hunting cat, he was on his guard, and concealing it under an appearance of being there more or less by accident and on his way to somewhere else. But there was ownership in every inch of him - ownership of house, and trees, and cats, and privacy, and solitude. He was holding a rake, and a lock of hair fell over one eye.'

28 See Claire Harman, Sylvia Townsend Warner: A Biography London: Chatto \& Windus, 1989, pp.128-130 on Frankfort Manor; and Sylvia Townsend Warner, Letters, ed. William Maxwell, London: Chatto \& Windus 1982, letter to Harold Raymond, 17.vi.1933, pp.23-24, and letter to Llewelyn Powys, 16.viii.1933, p.25.

29 Sylvia Townsend Warner, Letters, op .cit,, p.30, letter to Llewelyn Powys dated 24.iij.1934.

30 Left Review III: no.12, Jan.1938, quoted in Hanna Behrend, 'An Intellectual Irrelevance? Marxist Literary Criticism in the 1930s', in Andy Croft (ed.) (1998), p. 109.

31 See Ralph Miliband, Parliamentary Socialism: A Study in the Politics of Labour, London: Merlin Press, 1972, p.269 for the Pact as 'a profound shock' to the Left, and a discussion of CPGB's role in opposing the war.

\section{Copyrighted image removed}

